\title{
富士登山者の満足度の登山口別比較
}

\section{A comparative study of climbers' satisfaction classified by use of trailhead at Mt. Fuji}

\author{
山本 清龍*
}

\section{Kiyotatsu YAMAMOTO}

\begin{abstract}
Mt. Fuji has 4 major paths to the top and most climbers use 4 trailheads located at the mid-slope of the mountain (5th step) presently. It goes without saying that climbers' experience on 4 routes differs. In order to have climbers deeply satisfied with climbing experience, it is important to clarify the quality of experience and the attractiveness of route and to convey the information of them to potential climbers who have willingness to climb. This study aimed at evaluating the quality of climbing on the routes by using indicators of satisfaction level and employed a questionnaire survey. In concrete terms, the purpose of this study is 1) to grasp the characteristics of climbing on each route, 2) to evaluate the quality of climbing on the routes through climbers' satisfaction classified by use of trail head and 3) to make clear the relationship between the attribute of climbers and the satisfaction level. As a result, satisfaction level with some expectations related to landscape from the route, rural beauty and solitude and others differed. In other words, differences of the quality of climbing existed on 4 routes at Mt. Fuji.
\end{abstract}

Keywords: Mt. Fuji, climber, satisfaction, trailhead, attribute キーワード：富士山, 登山者, 満足, 登山口, 属性

\section{1. 研究の背景と目的}

富士山には主要な登山道が 4 つあり，大半の登山者が中腹に位 置する五合目あるいは新五合目と言われる登山口から登山を開始 する。五合目近辺を散策し六合目まで足を延ばす観光客もいる一 方で，登山者はほぼ例外なく頂上を目指し，独立峰の山であるこ とも手伝って目的地が頂上の一点に集中することがこの山の特徴 である ${ }^{1)}$ 。当然のことながら, 各登山口の立地や登山道の自然環 境が異なるため体験には差異があり, 加えて, トイレや登山道の 管理の状況，登山者同士の軒轢の有無によっても登山体験の質は 左右される。それゆえ, 自然環境特性の差異を含め登山者が自身 の体験をどのように評価しているかを把握する必要があるが，現 状では，4つの登山道間の登山体験の差異は不明である。いたず らに期待阻害を招かないためにも登山者の体験の質の差異を明ら かにし登山者に伝えることが必要である。そこで, 本研究では, 自然公園における登山利用をとりあげて，満足度の指標を用いて 各登山ルートの体験の差異について検討することを企図した。具 体的には，(1)登山ルート別の利用特性を明らかにすること，(2)各 登山口の利用者の満足度から，それぞれの登山ルートの体験の評 価を行うこと，(3)登山者属性が満足度にどのように関連している かを明らかにすること，の 3 点を目的とした。

ここで，登山が利用形態の主となる自然公園を例とし満足の概 念について整理しておくと，登山者は，公園が持つ魅力に応じて 体験できることを想定し，ある程度，現実的な期待を持って公園 を訪れる。登山者は，満足と不満は期待との相対関係の中で位置 づけられ，公園体験によって期待が充足されれば満足となり，期 待の充足が未達成に終われば不満として顕在化する ${ }^{2)}$ 。すなわち, 本研究では, 期待の充足度 (=満足度) の指標を用いて登山者の 体験の質を把握することにつとめた。

既往の知見として，期待，満足の指標を扱い検討した研究成果 は少なくない。たとえば, 自然体験サービス施設として国営公園 をとりあげて訪問者の属性や提供されているサービスの評価を把
握したもの ${ }^{3)}$ があり，満足に関しては，公園研究において満足を 取り扱うことの意義や問題点を整理したもの ${ }^{4)}$ がある。一方，人 の行動と経路に関する知見は都市計画分野 ${ }^{5)}$ や観光分野 ${ }^{6)}$ に蓄積 がある。しかし，意外なことに，自然公園のような野外空間の利 用経路と満足の関係を明らかにした成果は見あたらない。近い研 究成果として, 登山者の期待と登山経路の関連性を検討したもの 7) があるが, 経路ごとの登山体験の評価にまでは至っていない。

\section{2. 研究方法}

\section{(1) 研究対象地}

すでに触れたとおり，研究対象地は富士山である。富士山は独 立峰であるため登山者の目的地は唯一の山頂に集中するが，その 頂上に到達する主要な登山道が 4 つる (図一 1 )。古くは, 登山 口が浅間神社の社殿の隣接地など一合目よりも標高の低い場所に あったが, 五合目まで道路が敷設され駐車場が整備されたことで, 事実上五合目が 登山口として機 能しており, 本 研究でも登山口 は五合目，新五 合目を指すこと とする。4つの 登山口について みると, 南麓の 静岡県に登山口 を持つものとし て西側から順に 富士宮口，御殿 場口，須走口の 3 口があり，北 麓の山梨県に登

\footnotetext{
*東京大学大学院農学生命科学研究科
} 
山口を持つものとして 吉田口（河口湖口）が ある。年変動が多少あ るが，平成20（2008） 年を例にとると, 登山 者数が多い順に吉田口 $(7,8$ 月のみで 247,066 人, 全体の $57 \%$ ），富士宮口 $(136,574$ 人, $31 \%)$, 須走口 $(46,192$ 人, $11 \%)$, 御殿場口 (4,078 人， $1 \%)$ である ${ }^{8)}$ 。近 年は，富士山ブームと もいえるほど登山者数 が急増しており ${ }^{9)}$, 岩 場や崖での行列が将棋 倒しになる危険性を高 め登山者の安全や安心 を劦かしていること， 登山道の渋滞によって 混雑不快感が増大する 心理的な負の影響が懸 念されている。

\section{（2）調査手法}

富士登山者の属性と 意識，とくに満足度の 把握を意図して, 平成 21 (2009) 年8月 12〜 24 日の期間に，平日 4 日 (月水木金) と週末 2 日（土日）の計 6 日 間, 郵送回収式のアン ケート調査を実施した。 調査地は主要な 4 つの 登山口とし, 調査への 協力依頼に対し同意を 得ることができた 18 歳以上の下山者に対し て調査票の入った封筒

\begin{tabular}{|c|c|c|c|c|c|c|}
\hline 属性 & 登山口 & $\begin{array}{l}\text { 富 } \\
\text { 宮 }\end{array}$ & $\begin{array}{l}\text { 御 } \\
\text { 殿 } \\
\text { 場 }\end{array}$ & $\begin{array}{l}\text { 須 } \\
\text { 足 }\end{array}$ & $\begin{array}{l}\text { 吉 } \\
\text { 畐 }\end{array}$ & $\begin{array}{l}\text { 合 } \\
\text { 計 }\end{array}$ \\
\hline \multirow[t]{7}{*}{ 年齢 } & 10代 & 0 & 2 & 0 & 1 & 3 \\
\hline & 20代 & 30 & 7 & 23 & 36 & 96 \\
\hline & 30代 & 33 & 9 & 20 & 27 & 89 \\
\hline & 40代 & 31 & 11 & 7 & 16 & 65 \\
\hline & 50代 & 31 & 7 & 10 & 20 & 68 \\
\hline & 60 代 & 15 & 3 & 5 & 16 & 39 \\
\hline & 70代 & 7 & 0 & 0 & 5 & 12 \\
\hline \multirow[t]{2}{*}{ 性 } & 男 & 95 & 28 & 41 & $\underline{62}$ & 226 \\
\hline & 女 & 52 & 11 & 24 & 59 & 146 \\
\hline \multirow[t]{9}{*}{ 住所 } & 北海道 & 0 & 0 & 0 & 0 & 0 \\
\hline & 東北 & 4 & 0 & 0 & 1 & 5 \\
\hline & 関東 & $\underline{56}$ & 16 & 46 & 63 & 181 \\
\hline & 北陸 - 甲信越 & 10 & 1 & 3 & 9 & 23 \\
\hline & 東海 & 65 & 13 & $\underline{11}$ & $\underline{13}$ & 102 \\
\hline & 近畿 & $\underline{8}$ & 6 & 4 & 27 & 45 \\
\hline & 中国 & 1 & 1 & 0 & 4 & 6 \\
\hline & 四国 & 1 & 0 & 0 & 0 & 1 \\
\hline & 九州 & 2 & 2 & 0 & 4 & 8 \\
\hline 交通手段 & マイカー & 111 & 21 & 45 & $\underline{39}$ & 216 \\
\hline \multirow[t]{2}{*}{$*$} & 公共交通 & 48 & 22 & 18 & $\underline{24}$ & 112 \\
\hline & ッアーバス & $\underline{8}$ & $\underline{0}$ & $\underline{0}$ & 72 & 80 \\
\hline \multirow[t]{5}{*}{ 登山回数 } & 初めて & $\underline{58}$ & 19 & 30 & 77 & 184 \\
\hline & 2-3回 & 55 & 14 & 22 & 30 & 121 \\
\hline & 4-9回 & 25 & 5 & 9 & $\underline{10}$ & 49 \\
\hline & 10-19回 & 7 & 1 & 3 & 1 & 12 \\
\hline & 20 回以上 & 2 & 0 & 1 & 3 & 6 \\
\hline \multirow[t]{3}{*}{ 登山日程 } & 0泊 & 57 & 14 & 42 & $\underline{23}$ & 136 \\
\hline & 1泊 & 88 & 25 & $\underline{23}$ & 97 & 233 \\
\hline & 2泊 & 2 & 0 & 0 & 1 & 3 \\
\hline \multirow[t]{3}{*}{ ガイド } & 全部同行 & 12 & 0 & 0 & 46 & 58 \\
\hline & 一部同行 & $\underline{0}$ & 0 & 0 & 14 & 14 \\
\hline & 同行なし & 135 & 39 & 65 & $\underline{60}$ & 299 \\
\hline グループ & 1人 & 15 & 12 & 5 & 13 & 45 \\
\hline \multirow[t]{4}{*}{ 人数 } & $2 人$ & $\underline{26}$ & 9 & 24 & 37 & 96 \\
\hline & $3-5 人$ & 58 & 17 & 23 & 33 & $\underline{131}$ \\
\hline & 6-9人 & 28 & 1 & 11 & 7 & $\underline{47}$ \\
\hline & 10 人以上 & 19 & $\underline{0}$ & $\underline{2}$ & 30 & 51 \\
\hline グループ & 夫婦 & 17 & 4 & 9 & 23 & 53 \\
\hline \multirow[t]{4}{*}{ 構成＊ } & 家族 & 32 & 9 & 10 & 30 & 81 \\
\hline & カップル & 12 & 1 & 8 & 17 & 38 \\
\hline & 友人 & 62 & $\underline{9}$ & 27 & 48 & 146 \\
\hline & 同僚 & 40 & 4 & 11 & 18 & 73 \\
\hline \multirow[t]{2}{*}{ 登頂 } & 達成 & 121 & 33 & 53 & 96 & 303 \\
\hline & 断念 & 25 & 6 & 12 & 25 & 68 \\
\hline 合計 (人) & & 148 & 39 & 65 & 121 & 373 \\
\hline
\end{tabular}

注) 有効回答数 $=373$, 各カテゴリーの総数と有効回 答数の差は無回答を表す。ただし, 交通手段とグ 合一プ構成は複数回答 (*)。数字に付した下線と

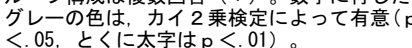

を手渡し，帰宅後に記入して投函してもらった。また，下山者の 中にはもともと散策を目的として頂上を目指さずに六合目で引き 返す日帰り観光客も含まれるため協力依頼前に確認して該当者を 除外した。それゆえ, 本研究で対象となった被験者はす心゙て頂上 を目指した登山者である。

\section{（3）アンケート調査票の構成と分析方法}

調査票には年齢や性別，住所の基本属性のほか，交通手段（複 数回答), 登山回数, 登山日程, ガイド同行の有無, グループの人 数之構成 (複数回答), 登頂の成否の登山特性を把握する項目を設 けた。その上で, 既往研究 ${ }^{10)}$ を参考にして, まず, 富士登山者の 期待を [1] 公園資源の享受, [2]野趣性・独居性の保持，[3]適切な 対人関係の構築，[4]情報や施設の円滑な利用，［5]清潔・快適な 空間の利用，の 5 つの期待に分類し，それぞれの期待に対して 3 〜6の指標を設け 23 の指標を作成した。また, 登山体験の全体の 評価を得るため総合満足度の指標を加え, 合計 24 の指標に対して 期待の充足度を測る 11 段階（0 から 10 点）の評価尺度を設け，4 つの登山道における体験の満足度の質問項目を設定した。なお， 本研究で扱う満足度については各評価点の度数分布を確認し，正

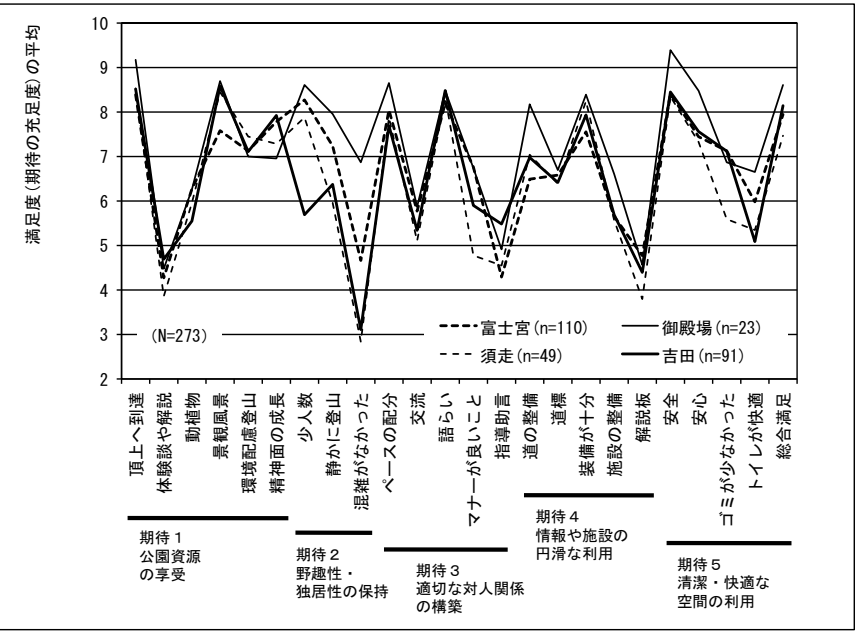

図一2 登山口別にみる登山者の満足度の平均 表-2 登山口別の各指標の平均值と分散分析の結果

\begin{tabular}{|c|c|c|c|c|c|c|}
\hline 期待 & 指標 & $\begin{array}{l}\text { 富士宮 } \\
(\mathrm{n}=110)\end{array}$ & $\begin{array}{l}\text { 御殿場 } \\
(\mathrm{n}=23)\end{array}$ & $\begin{array}{l}\text { 須走 } \\
(\mathrm{n}=49)\end{array}$ & $\begin{array}{c}\begin{array}{c}\text { 吉田 } \\
(n=91)\end{array}\end{array}$ & $\begin{array}{c}\text { 主効果 } \\
(P)\end{array}$ \\
\hline \multirow{6}{*}{$\begin{array}{l}\text { [1] } \\
\text { 公園資源 }\end{array}$} & 頂上へ到達 & 8.391 & 9.174 & 8.531 & 8.516 & 0.670 \\
\hline & 体験談や解説 & 4. 273 & 4. 478 & 3. 857 & 4. 692 & 0.256 \\
\hline & 動植物 & 6.273 & 6. 261 & 5. 959 & 5. 549 & 0.230 \\
\hline & 景観風景 & 7. $582 \mathrm{~b}$ & 8. $696 \mathrm{a}$ & 8. $449 \mathrm{a}$ & 8. 582 a & $0.002 * *$ \\
\hline & 環境配慮登山 & 7. 127 & 7. 000 & 7. 449 & 7. 110 & 0.809 \\
\hline & 精神面の成長 & 7. 782 & 6.957 & 7. 286 & 7. 923 & 0.162 \\
\hline \multirow{3}{*}{$\begin{array}{l}\{2] \\
\text { 野趣性 · } \\
\text { 独居性 }\end{array}$} & 少人数 & $8.273 \mathrm{a}$ & $8.609 \mathrm{a}$ & $7.878 \mathrm{a}$ & $5.692 \mathrm{~b}$ & $0.000 * *$ \\
\hline & 静かに登山 & 7. $236 \mathrm{ab}$ & 7. $957 \mathrm{a}$ & $5.959 \mathrm{c}$ & $6.374 \mathrm{bc}$ & $0.002 * *$ \\
\hline & 混雑がなかった & 4. $664 \mathrm{~b}$ & $6.870 \mathrm{a}$ & $2.837 \mathrm{c}$ & 3. $110 \mathrm{c}$ & $0.000 * *$ \\
\hline \multirow{5}{*}{$\begin{array}{l}{[3]} \\
\text { 適切な } \\
\text { 対人関係 }\end{array}$} & ペースの配分 & 8.045 & 8.652 & 7.878 & 7. 692 & 0.334 \\
\hline & 交流 & 5.773 & 5.870 & 5. 102 & 5. 341 & 0.345 \\
\hline & 語らい & 8. 200 & 8. 478 & 8. 327 & 8. 484 & 0.748 \\
\hline & マナーが良いこと & $6.764 \mathrm{a}$ & $6.739 \mathrm{a}$ & 4. $776 \mathrm{c}$ & 5. $901 \mathrm{ab}$ & $0.000 * *$ \\
\hline & 指導助言 & 4. $291 \mathrm{~b}$ & 4. $913 \mathrm{ab}$ & 4. $551 \mathrm{ab}$ & $5.484 \mathrm{a}$ & $0.022 *$ \\
\hline \multirow{5}{*}{$\begin{array}{l}{[4]} \\
\text { 情報や } \\
\text { 施設 }\end{array}$} & 道の整備 & $6.491 \mathrm{~b}$ & $8.174 \mathrm{a}$ & 7. $041 \mathrm{ab}$ & $6.978 \mathrm{ab}$ & $0.030 *$ \\
\hline & 道標 & 6.582 & 6. 696 & 6.388 & 6.418 & 0.920 \\
\hline & 装備が十分 & 7. 555 & 8. 391 & 8. 245 & 7. 934 & 0.232 \\
\hline & 施設の整備 & 5.655 & 6.609 & 5. 571 & 5. 692 & 0.360 \\
\hline & 解説板 & 4. 773 & 4. 565 & 3. 796 & 4. 396 & 0.102 \\
\hline \multirow{4}{*}{$\begin{array}{l}\text { [5] } \\
\text { 清潔. }\end{array}$} & 安全 & 8.409 & 9.391 & 8.347 & 8.451 & 0.140 \\
\hline & 安心 & 7. 445 & 8. 478 & 7. 327 & 7. 560 & 0.168 \\
\hline & ゴミが少なかった & 7. $127 \mathrm{a}$ & 6. $870 \mathrm{ab}$ & $5.592 \mathrm{~b}$ & 7. $121 \mathrm{a}$ & $0.004 * *$ \\
\hline & トイレが快適 & 5. 982 & 6.652 & 5. 347 & 5. 088 & $0.028 *$ \\
\hline 総合満足 & & $7.945 \mathrm{ab}$ & $8.609 \mathrm{a}$ & $7.469 \mathrm{~b}$ & $8.143 \mathrm{ab}$ & $0.017 *$ \\
\hline
\end{tabular}

注) 11 段階評定 (10点満点) で数值が大きいほど満足度が高く、同じ添付文字がついた数值間で は有意差なし。また, 添付文字が付いていない指標では 4 つの登山口で有意差なし。分散分析 の主効果については $*: p<.05 、 * *: p<.01$ 、多重比較検定は Tukey's HSD testによる。 $(\mathrm{N}=273)$

規分布すると仮定した上で分析を行った。

\section{3. 結果と考察}

\section{（1）回答者の属性}

4 つの登山道の評価の差異を明確にするため, 登山と下山で異 なる登山口を利用した回答者 2 人を除き同じ登山口を利用した回 答者を解析対象とした結果, 有効回答は 373 , 調査票の配布数 1, 145 に対する回収率は約 $32.8 \%$ となった。

表一 1 は回答者の属性である。まず全体でみると，年齢は 20 代が最も多く 30 代と合わせると全体の約半数を占め, 性別では男 性が約 6 割と女性よりも多かった。誘致圈は広く関東地方からの 登山者が約半数, 次いで東海地方からの登山者が約 3 割であり, 交通手段はマイカーが約 6 割を占めた。また, 富士登山の回数は 約半数が初めて, 登山日程は約 6 割が 1 泊 2 日であった。さらに, 約 8 割の登山者はガイドが同行しない登山形態であり, グループ 人数は 3-5 人が $35 \%$, 友人同士の登山が約 4 割で最も多かった。 最後に登頂は, 約 8 割の回答者が成功しており, 残りの約 2 割の 
表-3 回答者の属性と満足度の関係

\begin{tabular}{|c|c|c|c|c|c|c|c|c|c|c|c|c|c|c|c|c|c|c|c|c|c|c|c|c|}
\hline \multirow[b]{2}{*}{ 期待 } & \multirow[b]{2}{*}{ 満足指標 } & \multicolumn{2}{|c|}{ 年齢 } & \multicolumn{2}{|c|}{ 性 } & \multicolumn{2}{|c|}{$\begin{array}{l}\text { 交通 } \\
\text { 手段 }\end{array}$} & \multicolumn{2}{|c|}{\begin{tabular}{l|} 
登山 \\
数
\end{tabular}} & \multicolumn{3}{|c|}{$\begin{array}{l}\text { 登山 } \\
\text { 日程 }\end{array}$} & \multicolumn{3}{|c|}{ ガイド } & \multicolumn{3}{|c|}{$\begin{array}{c}\text { グル-プ } \\
\text { 人数 }\end{array}$} & \multicolumn{4}{|c|}{$\begin{array}{c}\text { グループ } \\
\text { 構成 }\end{array}$} & \multicolumn{2}{|c|}{ 登頂 } \\
\hline & & \begin{tabular}{|c|}
2 \\
0 \\
代 \\
\end{tabular} & \begin{tabular}{|c|}
5 \\
0 \\
代 \\
\end{tabular} & 男 & 女 & $\begin{array}{l}又 \\
1 \\
\text { 多 } \\
\end{array}$ & $\begin{array}{l}\text { ツ } \\
\text { ア } \\
\text { バ } \\
\text { ス }\end{array}$ & $\begin{array}{l}\text { 初 } \\
\phi \\
\tau \\
\tau\end{array}$ & $\begin{array}{l}2 \\
5 \\
3 \\
\text { 回 } \\
\text { 貝 }\end{array}$ & $\begin{array}{l}0 \\
\text { 泊 }\end{array}$ & $\begin{array}{ll}1 \\
\text { 泊 }\end{array}$ & 2 & \begin{tabular}{|l|} 
全 \\
蔀 \\
行
\end{tabular} & $\begin{array}{l}- \\
\text { 部 } \\
\text { 行 }\end{array}$ & $\begin{array}{l}\text { 同 } \\
\text { 行 } \\
\text { な } \\
\llcorner\end{array}$ & $\begin{array}{ll}1 \\
\curlywedge\end{array}$ & 人) & \begin{tabular}{l||}
1 \\
0 \\
以 \\
上
\end{tabular} & \begin{tabular}{|l|} 
婦 \\
\end{tabular} & \begin{tabular}{l|} 
觉 \\
$>0$ \\
$ル$
\end{tabular} & \begin{tabular}{l|l} 
友 \\
人
\end{tabular} & & $\begin{array}{l}\text { 達 } \\
\text { 成 }\end{array}$ & \\
\hline \multirow{6}{*}{$\begin{array}{l}\text { 公園資源の } \\
\text { 受 }\end{array}$} & 頂上へ到達 & & & & & & & & & $\overline{-}$ & + & & & & & & & . & & & & & + & - \\
\hline & 体験談や解説 & - & & & & & + & & & - & + & & + & & - & & & . & 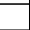 & & & & 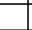 & \\
\hline & 動植物 & & & & & & & & & & & & & & & + & & & & & & & & \\
\hline & 景観風景 & & & - & + & & & & & & & & & & & & & & & & & & & \\
\hline & 環境配盧登山 & & & & & & & & & & & & 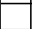 & & & + & & 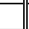 & 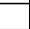 & & & & 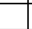 & \\
\hline & 精神面の成長 & & & - & + & & + & & 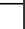 & & & & 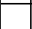 & & 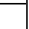 & 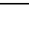 & & 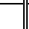 & 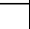 & 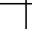 & - & & + & - \\
\hline \multirow{3}{*}{$\begin{array}{l}\text { 野趣性・独 } \\
\text { 恬性の保持 }\end{array}$} & 少人数 & & & & & + & - & - & + & & & & - & - & + & & & -1 & & & 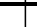 & & . & \\
\hline & 静かに登山 & & & & & & & & & & & & & & & & & & & & & & & \\
\hline & 混雓がなかった & & & & & & & & & & & & - & & + & + & & 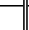 & 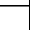 & - & 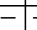 & - & & \\
\hline \multirow{5}{*}{$\begin{array}{l}\text { 適切な対人 } \\
\text { 関係の構築 }\end{array}$} & ペースの配分 & & & & & & & & & & & - & & & & + & & & 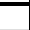 & & & & + & - \\
\hline & 交流 & & & & & & & & & & . & & & & & & & 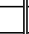 & 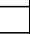 & & & & 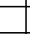 & \\
\hline & 語らい & & & & & & & & & & & & & & & & & & 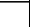 & & & & 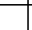 & \\
\hline & ママナーが良いこと & & & & & & & & & - & + & & & & & & & & - & & & & - & \\
\hline & 指導助言 & & & & & - & + & & & - & + & & + & & - & & & + & & & & & 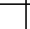 & \\
\hline \multirow{5}{*}{$\begin{array}{l}\text { 情報・施設 } \\
\text { の円滑な利用 }\end{array}$} & 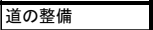 & - & & & & & & & & & + & & & & & & & & & & & & 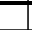 & \\
\hline & 道標 & - & & & & & & & & & 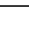 & & & & & & & & 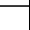 & & & & - & \\
\hline & 装備が十分 & - & & & & & & & & & & & & & & & & & & & & & & \\
\hline & 施設の整備 & & & & & & & & & & & & & & & & & & & & & & & \\
\hline & 解説板 & - & + & & & & & & & & + & & & & & & & & 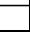 & 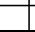 & & & 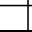 & \\
\hline \multirow{4}{*}{$\begin{array}{l}\text { 清政 ·快適な } \\
\text { 空間の利用 }\end{array}$} & 安全 & & & & & & & - & & & + & & & & & & & & & & & & & \\
\hline & 安心 & - & + & & & - & + & - & & - & + & & & & - & & & & & - & & & 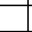 & \\
\hline & ゴミが少なかった & & & & & & & & & & & & & & & & & & & & & & -1 & + \\
\hline & \begin{tabular}{|l|} 
トイレが快適 \\
\end{tabular} & - & & & & & & & & & & & & & & & - & & 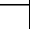 & - & & & & \\
\hline \multicolumn{2}{|c|}{ 総合満足 } & & & & & & + & & & - & + & & & & - & & & & 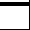 & 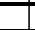 & & & 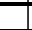 & \\
\hline
\end{tabular}

だった」（7.96）がやや高い満足度だった一方で, 「道の標識（案内板）がよく整備されていた」(4.54) が低い満足度として評価された。最後に, [5]清潔・快 適な空間の利用の期待では, すでに触れたとおり「安 全に登ることができた」ことが高い満足につながって いたが，「トイレが清潔，快適だった」(5.77) という 指標においては高い評価を得られていなかった。

\section{（4）登山口別の満足度の差異}

24 の指標について登山口別の満足度の差異を明ら かにするため, 分散分析 (Tukey's HSD test, p<. 0)5 を用いて多重比較検定を行った（表一2）。その結果， まず, [1] 公園資源の享受の期待では, 吉田口を利用し た回答者の方が富士宮口を利用した回答者よりも「景 観・風景」を高く評価していることが明らかとなった。 理由として, 吉田口は 4 口の中で最も東側に位置し, 反対に富士宮口は 4 口の中で最も西側に位置すること から, 登山道からの景観の差異に加えて, 御来光を見 る際の立地の良さが評価の差異となって表れたと考え られる。次に，[2]野趣性・独居性の保持の期待では, 利用した登山口間で 3 つのすべての指標において満足 度に差異が見られ, 概して, 吉田口では「少人数」で 登山できなかったこと,「静かに登山」できる状況ではなかったこ と，「混雑」があったことにより評価が低いことが明らかとなった。 反対に，御殿場口ではそれらの指標で評価が高く，そのほかの富 士宮口と須走口の評価は中間に位置していた。先述のとおり, 吉 田口からの登山者数が多いのに対し御殿場口の利用者は少なく, このことが野趣性・独居性の保持に関わる満足に影響を及ぼして いると考えられる。[3]適切な対人関係の構築の期待では，「マナ 一」と「指導・助言」において登山口間に差異が見られ，富士宮 口や御殿場口でマナーの良さが評価されているのに対し, 須走口 で評価が低くなっていた。また，吉田口は富士宮口よりも「山小 屋や他の登山者から登り方について指導、助言をもらった」こと が満足につながっていた。須走口が他の登山口よりもマナーが悪 いと評価を受けることに対し理由を求めることは難しいが，須走 口の登山者層に 20 代の若年層が多いこと, 夜行登山を含め山小屋 に宿泊せずに登頂を目指寸登山者が多いこと，ガイドが同行しな い登山者が多いこと，これらのことがマナ一の低下を招く原因に なっていると考えられる。そのほか, [4]情報や施設の円滑な利用 の期待では,「道の整備」において御殿場口が富士宮口よりも高い 評価を得ていた。[5]清潔・快適な空間の利用の期待では,「ゴミ」 が少なかったことについて富士宮口と吉田口が高い評価を受けて いるのに対し, 須走口ではそれら 2 口よりも有意に評価が低かっ た。最後に, 総合満足度では, 御殿場口が須走口よりも有意に高 かった。

\section{（5）登山者の属性と満足度の関係}

前節の分析により, 各登山口の利用者の登山体験の評価の差異 を明らかにしたが，その評価の差異が歩いた登山道の自然的，社 会的特性によるものと即断することはできない。というのも，年 齢や性別などの基本属性, 登山回数や登山日程などの登山特性そ のものが評価に対する一定の影響を及ぼしていると考えられるか らである。そこで, 登山者の属性と 24 の指標がどのような関係を 持つかを明らかにするため, 数量化 I 類分析を通して, 属性と満 足度の単相関について有意なものを把握した。表一 3 は, 表一 1 で扱ったすべての属性と 24 の満足指標の関係を, 高い満足評価を 示す属性と, 低い満足評価を示寸属性に区別して, 有意なものの みを一覧として整理したものである。

まず，基本属性の年齢からみると，20 代の若年層では「体験談 や解説」「安心」や「トイレが快適」といった指標で評価が低く, 
[4]情報・施設の円滑な利用の期待に関わる多くの指標で評価が低 下していた。また，50 代の中高年層では「解説板」や「安心」の 指標で評価が高くなっていた。さらに，性別では男性よりも女性 で「景観風景」「精神面の成長」の満足が高くなっていた。

次に，登山特性を交通手段から順にみると，ツアーバスで満足 度が高くなる傾向があるほか, ツアーバスを降りて団体行動をと る行動特性を反映して「少人数」で登山できたことに対する満足 が低下していた。反対に，マイカー利用者は「少人数」の満足が 高かったが「安心」感が低下していた。登山回数では, 初めての 登山者で「少人数」「安全」「安心」の満足度が低下するのに対し， 2-3 回目の登山者で「少人数」の満足度が高くなっていた。登山 日程では，山小屋に宿泊しなかった登山者で満足度が低下する項 目が数多くあるのに対し，山小屋に 1 泊した登山者は多くの指標 で満足度が高くなる傾向がみられ顕著な差異があることが明らか となった。そのほか，2泊した登山者では「ペースの配分」で満 足が低下しており，ペースが落ちていないかなど登山行程に検討 すべき課題のあることが示唆された。ガイドの有無では, 全ての 行程でガイドが同行する登山形態で「体験談や解説」を聞くこと ができた，「環境に配慮した登山」ができたことに対する満足度が 高く, ガイドの解説や指導の効果があらわれているとみることが できる。しかし，「少人数」「混雑がなかった」の指標で評価が低 下しており，ガイド同行登山が団体であること，行動の自由度が 相対的に低いことに起因して野趣性や独居性が低下している可能 性を指摘できる。一方，ガイドが同行しない登山形態では，全行 程でガイドが同行する登山形態と比べて対照的な評価を行ってお り, 加えて,「安心感」や「総合満足度」が低下していた。グルー プ人数では, 1 人の登山者で評価が高くなる指標が複数あり，「動 植物」を見ることができたこと，「自然環境への影響が少ない登山 をすることができた」(環境配慮登山)ことに対する満足度が高か った。また，「少人数」の登山や良い「ペース配分」で登ることが できたことに対する満足も高く, 行動の自由度の高さもうかがえ る。また, 2 人の登山者では「トイレが快適」であることについ て満足が低下していた。そのほか，10 人以上の登山者では，「少 人数」の満足度が低下し，登り方に関する「指導助言」が満足度 を向上させていた。グループ構成では，カップルと友人，同僚の グループでは「混雑がなかった」の満足度が低下し，夫婦では， 「マナー」の評価が低下していた。一方，カップルでは「安心」 して登山できたこと，「トイレが快適」であることが不満として現 れており，トイレの整備水準に関する情報や安心感を提供する取 り組みも望まれる。最後に，登頂の成否による差異についてみる と，登頂を果たした登山者で「頂上へ到達」「精神面の成長」「ぺ 一ス配分」の満足が高かった。反対に，途中で登頂を断念した登 山者では，これらの3つの指標で満足度が低下しており，登頂未 達成の一つの要因を自身の精神面だけでなくペース配分の拙さに も求めている様子がうかがえる。そのほか, 登頂の成否によって 「ゴミが少なくてよかった」ことに対する満足度に差異がみられ た。登頂を断念した登山者が頂上に到達していないということを 考慮すると，評価の差異の理由として頂上付近にゴミが多かった 可能性を指摘できる。

\section{4. まとめ}

研究結果から, 登山口によって富士登山者の属性には違いがあ り, 登山口ごとにいわば個性があることが明らかとなった。また, 利用寸る登山口によって満足評価にも差異があること, 属性によ って満足評価が異なることが明らかとなった。ここでは，研究成 果を 4 つの登山口の登山特性と満足の観点から総括し，同時に， 管理・計画上の課題についても整理する。

静岡側の 3 口の中で最も登山者数が多く東海地方からの立関口
として機能している富士宮口では, マイカーでアクセスしガイド が同行しない登山者が多かった。また，同僚で構成され 6-9人の 中規模のグループが多かった。とくに，マイカー利用者とガイド が同行しない登山者では, 指導助言を受ける機会が少ないこと, 安心感が低下することによって満足が低下しており，登山者に介 入し安心感を提供していくことが求められる。次に，4 口の中で 最も登山者数が少ない御殿場口では, 公共交通を利用しガイドが 同行しない登山形態が多かった。この登山口を利用した登山者は, 総合的な満足を含めて多くの指標で評価が高く, 4 口の比較の中 で言えば質の高い登山体験を享受できる登山口といえる。しかし， 前述のとおり, ガイドが同行しない登山形態では, 体験談や指導, 助言を聞く機会が少なく, 総合的な満足が低い傾向にあるため, 登山者の機動性を維持するとしても，さらに良質の登山体験の提 供について検討寸る余地があるといえる。その御殿場口に次いで 登山者数が少なく, 関東地方からマイカーで利用される須走口は, 20 代の登山者が多く, ガイドが同行せずに, 日帰りあるいは夜行 登山を行い, グループの規模が 2 人と比較的小さなグループを作 っていた。須走口で顕著にみられた属性の登山者は, ほとんどの 指標で満足評価が低く, 総合満足度も御殿場口より有意に低く, 登山体験を改善する余地は大いにある。とくに，登山者層に 20 代の若年層が多いこと, 夜行登山を含め山小屋に宿泊せずに登頂 を目指している人が多いこと, ガイドが同行しない登山者が多い ことを考慮すれば，現地において登山者と接点を持つことは難し く, 年齢層に合わせて適切なメディアを通して情報提供すること が望まれる。最後に，4 口の中で最も登山者数が多く, 関東地方 だけでなく近畿地方からの登山者の立関口になっている吉田口は, 女性が多く, ツアーバスの利用者, 初めてあるいは 2-3 回目の相 対的に登山経験の少ない登山者が多かった。また，ガイドが同行 し，10 人以上の大きなグループを形成し，1 泊 2 日の行程で登山 する人が多かった。この登山口に多い登山者属性は, 多くの指標 で満足度が高くなる傾向があるものの, 登山する際のグループの 大きさや混雑に関わる指標で満足が低下しており，人の多さが大 きな問題である。また, 初めての登山者は, 安全, 安心に関わる 指標で満足が低下しており, 登山方法やリスクとの向き合い方な ど初心者むけの情報提供の機会が期待される。

最後に, 本研究は静岡県戦略課題研究 (2008-2009 年度受託研 究）として実施したものであり, 関係各位のご理解とご協力に感 謝する。また, 研究結果をまとめるにあたり静岡県観光政策課, 富士吉田市富士山課には貴重な資料を提供して頂いた。ここに記 してお礼を申し上げる。

\section{引用 · 参考文献}

1) 山本清龍 (2009)：山岳観光の動向一富士登山 : 山林1505，58-65

2）山本清龍（2006）: 自然公園における利用者数が利用者の期待に及ぼす影響 に関する研究 : 東京大学博士論文, 1-11

3）岩谷祐子他（2008）：自然体験サービス提供施設としての国営木曽三川公園 に対する利用者評価に関する研究: ランドスケープ研究 71(5), 623-628

4) Manning, Robert E. (1999) : Studies in outdoor recreation : Oregon State University Press, 374pp.

5）たとえば, 牧大佑他 (2008) 散歩に適した空間整備がなされた地区における 散歩行動の実態と散歩経路変化に関寸る研究: 都市計画論文集 43, 409-414 6）たとえば, 西井和夫他（2003）観光地エリアイメージと行動特性に基づく歩 行者系回遊空間整備方法一京都洛東エリアを対象として: 観光研究 14 (2), 37-45 7 ) 小林昭裕他 (213) : 大雪山国立公園の登山者が来訪動機の充足を期待した区 域と登山経路 : ランドスケープ研究58(5), 213-216

8) 静岡県観光局(2008) 富士山への登山者数の状況，富士吉田市富士山課(2008) 富士山登山者調心゙

9）読売新聞（2010）: 富士山ブームで苦悩，8月31日

10）山本清龍（2007）：自然公園利用者の富士登山に対する期待と期待阻害 : 環 境情報科学論文集 21, 129-134 